\title{
Home-based program of maintaining unresponsiveness in children with allergic reactions to larger amounts of peanuts
}

DOI:

10.1016/j.anai.2017.09.064

\section{Document Version}

Accepted author manuscript

Link to publication record in Manchester Research Explorer

Citation for published version (APA):

Arkwright, P., Sharma, V., Ewing, C. I., \& Hughes, S. (2018). Home-based program of maintaining unresponsiveness in children with allergic reactions to larger amounts of peanuts. Annals of Allergy, Asthma, \& Immunology , 120(5), 539-540. https://doi.org/10.1016/j.anai.2017.09.064

Published in:

Annals of Allergy, Asthma, \& Immunology

\section{Citing this paper}

Please note that where the full-text provided on Manchester Research Explorer is the Author Accepted Manuscript or Proof version this may differ from the final Published version. If citing, it is advised that you check and use the publisher's definitive version.

\section{General rights}

Copyright and moral rights for the publications made accessible in the Research Explorer are retained by the authors and/or other copyright owners and it is a condition of accessing publications that users recognise and abide by the legal requirements associated with these rights.

\section{Takedown policy}

If you believe that this document breaches copyright please refer to the University of Manchester's Takedown Procedures [http://man.ac.uk/04Y6Bo] or contact uml.scholarlycommunications@manchester.ac.uk providing relevant details, so we can investigate your claim.

\section{OPEN ACCESS}


Allergy, Asthma \& Immunology

Elsevier Editorial System(tm) for Annals of

Manuscript Draft

Manuscript Number: 17-07-0353R2

Title: Home-based programme of maintaining unresponsiveness in children with allergic reactions to larger amounts of peanuts

Article Type: Letters

Keywords: food allergy; peanut; immunotherapy

Corresponding Author: Dr. Peter D Arkwright, MB, D Phil

Corresponding Author's Institution: University of Manchester

First Author: Peter D Arkwright, MB, D Phil

Order of Authors: Peter D Arkwright, MB, D Phil; Vibha Sharma, MD; Carol I Ewing, MD; Stephen M Hughes, MD, PhD

Suggested Reviewers:

Opposed Reviewers:

Response to Reviewers: Thank you to you the Editors and Reviewers for assessing our revised manuscript.

Point by point response:

Reviewer \#2:

1. Reference 1 and 2 have now been reordered in the first two sentences of the text and in the reference list.

Reviewer \# 4 :

1. Line 7, the sentence has been changed as suggested to • . "that desensitization and to some extent sustained unresponsiveness can be achieved. . 


\section{Cover Letter}

Thank you to you the Editors and Reviewers for assessing our revised manuscript.

Point by point response:

Reviewer \#2:

1. Reference 1 and 2 have now been reordered in the first two sentences of the text and in the reference list.

Reviewer \#4:

1. Line 7, the sentence has been changed as suggested to ... "that desensitization and to some extent sustained unresponsiveness can be achieved. . . 
1 Home-based programme of maintaining unresponsiveness in children with allergic

2 reactions to larger amounts of peanuts

3

4 Peter D Arkwright ${ }^{1,2}$, MD, PhD, Vibha Sharma ${ }^{2}$, MD, Carol I. Ewing ${ }^{2}$, MD, Stephen M.

5 Hughes $^{1,2}, \mathrm{MD}, \mathrm{PhD}$.

6 University of Manchester ${ }^{1}$, Department of Paediatric Allergy \& Immunology, Royal

7 Manchester Children's Hospital ${ }^{2}$, Manchester, United Kingdom

8

9 Correspondence to: Dr P D Arkwright, University of Manchester, Royal Manchester

10 Children's Hospital, Oxford Rd., Manchester, M13 9WL, United Kingdom, Tel +44 161701

11 0678, Fax +44 161701 0864, email peter.arkwright@nhs.net

12

13 This study was funded by the University of Manchester

14

15 Word Count 976; Number of figures and tables: 1 
1 Allergists currently advise the majority of patients with peanut allergy to observe life-long

2 avoidance. This is in contrast to milk and egg allergy, where many children are partly tolerant

3

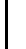

6 immunotherapy have demonstrated that patients vary in the amount of peanut needed to

7 trigger a reaction and that desensitization and to some extent sustained unresponsiveness can

8 be achieved in children and adolescents..$^{2-4}$ There are currently no reliable biomarkers

9 identifying which children will outgrow their peanut allergy, or only react to larger amounts

10 of the food.

At our tertiary pediatric allergy referral center in the United Kingdom, 41 (32\%) of 130 children undergoing supervised open oral peanut challenges between 2012 - 2016 developed objective signs of an allergic reaction. Of these 41 patients, 31 (76\%) reacted after eating more than one peanut $\left(200 \mathrm{mg}\right.$ total weight) ${ }^{5}$ We hypothesized that in this group of children with a higher threshold of reactivity and non-anaphylactic reactions, it should be possible to maintain and increase the threshold amount of peanut required to induce an allergic reaction by regular exposure, irrespective of allergy test results. As proof of principle, Garvey et al from Cork, Ireland recently published the results of their home-based oral peanut immunotherapy (OIT) programme. It was not a formal research study but a case series based on clinical observations performed with motivated families in a university based clinical practice. They described 10 children who previously experienced non-anaphylactic reactions to $4 \mathrm{~g}$ or more of peanut during supervised hospital oral challenge. ${ }^{6}$ After six months on their programme, all children were able to tolerate more peanut than the eliciting threshold at the initial oral challenge: a minimum cumulative dose of $4 \mathrm{~g}$ and up to $16 \mathrm{~g}$ of peanut. There were no significant adverse events and no need for additional clinical reviews. 
From September 2015, our center supported a small group of children through a

similar home-based peanut OIT programme. The aim of this case series review is to describe our center's experience in maintaining partial non-responsiveness to peanut. After formal oral peanut challenge, six children who had tolerated the equivalent of one or more $(\geq 200 \mathrm{mg}$ by weight) peanuts in their oral challenge were invited to start consuming sub-threshold amounts of peanut as determined by their oral challenge. Joining the programme was a collaborative decision made after discussions initiated by the pediatric allergist. The most common reason for patients being excluded was that the child had no interest in eating, or did not like the taste of peanuts.

Although the aim was to start patients on a quarter of the threshold amount of either peanut butter or shelled peanuts that caused the allergic reaction in open challenge, the starting amount was individualized depending on how much peanut the patient felt comfortable eating. Patients were asked to consume the peanuts or peanut butter at least three times a week, doubling the amount, up to a maximum of 15 peanuts three times a week. Progress up the food ladder depended on their confidence and that of their parents and was formally reviewed in clinic every 2 to 3 months. If patients suffered from an allergic reaction, they were instructed to stop eating the peanuts and contact their clinician. Patients who did not eat the peanut-containing food for more than four weeks were asked to contact their physician before recommencing the food. During the programme, no patients informed the clinical team that they had missed more than four weeks. Allergy management plans, including use of epinephrine auto-injectors were provided and regularly reviewed. As with the Cork programme, ethics approval was not sought as children started with a quantity of food they already tolerated. Procedural details were clearly documented in the clinical records and clinic letters to the primary physician were copied to the family. 
Data from the six children in the programme aged between 1 to 16 years who reacted

to $200 \mathrm{mg}$ or more of peanut on formal open challenge with urticaria, superficial angioedema and/or vomiting, but no breathing problems are described in Table I. Four to 24 months into their programme all children tolerate one to six peanuts three times a week. None of the children have had significant allergic reactions during updosing or the maintenance phase, nor have they required additional visits to the allergy center outside routine review.

Furthermore, none of the patients contacted the physician between appointments because of allergic reactions.

This case series, albeit of a small number of children, independently supports that of Garvey et al. ${ }^{6}$ By selecting children with well-controlled asthma and non-anaphylactic reactions to the equivalent of one or more peanuts, we suggest that is possible to safely maintain and increase peanut non-responsiveness through a home OIT programme. Patients will continue to be encouraged to eat the equivalent of up to 15 peanuts (tablespoon of peanut butter) 3 times a week, although some will only feel comfortable with smaller amounts. As with any immunotherapy programme, the main concern is anaphylaxis either during updosing, intercurrent infection or because of prolonged periods of noncompliance. Allergy management plans need to be reviewed regularly, including competence and availability of epinephrine auto-injectors. Patients should be carefully monitored for adverse events such as allergic reactions and eosinophilic esophagitis. ${ }^{7}$

In summary, published studies indicate that complete avoidance of foods to which children were previously partly tolerant can lead to more severe allergic reactions, while continuing to consume the food in an amount and form that is tolerated maintains nonresponsiveness. ${ }^{8-9}$ We suggest that regular ingestion of tolerated amounts of peanutcontaining food, as with cow's milk and egg, may reduce rather than increase the risk of 
74 future serious allergic reactions. Formal studies are required to determine if this is indeed the 75 case.

76

77

Peter D Arkwright ${ }^{1,2}, \mathrm{MD}, \mathrm{PhD}$

78 Vibha Sharma ${ }^{2}$, MD

79 Carol I. Ewing ${ }^{2}$, MD

80 Stephen M. Hughes ${ }^{1,2}$, MD, PhD

81 University of Manchester ${ }^{1}$, Department of Paediatric Allergy \& Immunology, Royal 82 Manchester Children's Hospital ${ }^{2}$, Manchester, United Kingdom 


\section{References}

\section{[1ㄹ] Nurmatov U, Dhami S, Arasi S, et al. Allergen immunotherapy for IgE-mediated food} allergy: a systematic review and meta-analysis. Allergy 2017:72:113-1147.

[21] Ho MK, Wong WH, Heine RG, Hosking CS, Hill DJ, Allen KJ. Early clinical predictors of remission of peanut allergy in children. J Allergy Clin Immunol. 2008;121:731-6.

\section{[2] Numav U, Bhami S, Arasis, et al. Allergen immum allergy: asystematie review and andysis. Allergy 2017:72:113-1147.}

[3] Jones SM, Sicherer SH, Burks AW, et al. Epicutaneous immunotherapy for the treatment of peanut allergy in children and young adults. J Allergy Clin Immunol. 2017;139:12421252.

[4] Vickery BP, Berglund JP, Burk CM, et al. Early oral immunotherapy in peanut-allergic preschool children is safe and highly effective. J Allergy Clin Immunol. 2017;139:173181.

[5] Rajput S, Sharma V, Hughes SM, Ewing CI, Arkwright PD. Reply to van Erp et al: allergy testing in predicting outcome of open food challenge to peanut. J Allergy Clin Immunol 2017, Jun 14.

[6] Garvey AA, O'Sullivan D, Hourihane JOB. Home-based induction of sustained unresponsiveness in children with mild reactions to high doses of peanut. J Allergy Clin Immunol Pract 2017; Apr 28.

[7] Semancik E, Sayej WN. Oral immunotherapy for peanut allergy induces eosinophilic esophagitis: three pediatric case reports. Pediatr Allergy Immunol. 2016;27:539-41.

[8] Young MC. Elimination Diets in Eczema. A Cautionary Tale. J Allergy Clin Immunol Pract. 2016;4:237-8. 
24 [9] Chang A, Robison R, Cai M, Singh AM. Natural History of Food-Triggered Atopic

25 Dermatitis and Development of Immediate Reactions in Children. J Allergy Clin Immunol 26 Pract. 2016;4:229-36.e1. 
Table I Characteristics of patients undergoing home peanut OIT

\begin{tabular}{|c|c|c|c|c|c|c|c|}
\hline $\begin{array}{l}\text { Patient } \\
\text { number }\end{array}$ & $\begin{array}{l}\text { Age } \\
\text { (years) }\end{array}$ & Gender & $\begin{array}{l}\text { Clinical history of reactions to } \\
\text { peanut }\end{array}$ & $\begin{array}{l}\text { SPT } \\
(\mathrm{mm})\end{array}$ & $\begin{array}{l}\text { total IgE / peanut } \\
\text { IgE/ Ara h2 } \\
(\mathrm{kAU} / \mathrm{L})\end{array}$ & $\begin{array}{l}\text { Doctor supervised peanut } \\
\text { oral food challenge }\end{array}$ & Home peanut OIT programme \\
\hline 1 & 17 & Female & $\begin{array}{l}\text { At } 4 \text { years ate peanuts, within } 5 \\
\text { minutes urticaria, facial } \\
\text { swelling, husky voice, cold \& } \\
\text { clingy. } \\
\text { Mild asthma: no steroid inhaler } \\
\text { Grass-induced rhinitis: on grass } \\
\text { SLIT }\end{array}$ & 10 & $\begin{array}{l}1000 \\
12.8\end{array}$ & $\begin{array}{l}\text { At } 14 \text { years failed stage } 5 \text { : } \\
5 \mathrm{~g} \text { peanut: urticaria, } \\
\text { angioedema, vomiting. } \\
\text { Given antihistamine only. }\end{array}$ & $\begin{array}{l}24 \text { months into home peanut OIT } \\
\text { programme. } \\
\text { No acute allergic reactions. } \\
\text { Started with } 1 \text {, now tolerating } 6 \\
\text { peanuts, 3/week }\end{array}$ \\
\hline 2 & 15 & Female & $\begin{array}{l}\text { At } 2 \text { years ate roasted peanut, } \\
\text { within } 5 \text { minutes itchy mouth, } \\
\text { cough listless, agitated. } \\
\text { No asthma }\end{array}$ & 18 & $\begin{array}{l}340 \\
8.1 \\
5.1\end{array}$ & $\begin{array}{l}\text { At } 12 \text { years failed stage } 4 \text { : } \\
\text { 1g peanut, lip swelling. } \\
\text { Given antihistamine only. }\end{array}$ & $\begin{array}{l}20 \text { months into home peanut OIT } \\
\text { programme. } \\
\text { No acute allergic reactions. } \\
\text { Started with } 1 / 4 \text {, now tolerating } 4 \\
\text { shelled peanuts, 3/week }\end{array}$ \\
\hline 3 & 7 & Male & $\begin{array}{l}\text { At } 1 \text { year ate peanut butter, } \\
\text { within } 5 \text { minutes facial } \\
\text { angioedema only. } \\
\text { Mild asthma: no steroid inhaler }\end{array}$ & 7 & $\begin{array}{l}910 \\
3.4 \\
0.7\end{array}$ & $\begin{array}{l}\text { At } 6 \text { years, failed stage } 5: \\
5 \mathrm{~g} \text { peanut: large vomit. }\end{array}$ & $\begin{array}{l}13 \text { months into home peanut OIT } \\
\text { programme. } \\
\text { No acute allergic reactions. } \\
\text { Started with } 2 \text {, now tolerating } 9 \\
\text { peanuts, 3/week }\end{array}$ \\
\hline
\end{tabular}




\begin{tabular}{|c|c|c|c|c|c|c|c|}
\hline 4 & 8 & Male & $\begin{array}{l}\text { At } 6 \text { years, ate a peanut- } \\
\text { containing chocolate bar, within } \\
30 \text { minutes developed } \\
\text { generalized urticaria only. } \\
\text { Mild asthma: no steroid inhaler } \\
\text { Mild allergic rhinitis }\end{array}$ & 10 & $\begin{array}{l}903 \\
1.1 \\
1.3\end{array}$ & $\begin{array}{l}\text { At } 7 \text { years, failed stage } 5 \text { : } \\
5 \mathrm{~g} \text { peanut: localized } \\
\text { urticaria on torso }\end{array}$ & $\begin{array}{l}6 \text { months into home peanut OIT } \\
\text { programme. } \\
\text { No acute allergic reactions. } \\
\text { Started with } 1 \text {, now tolerating } 4 \\
\text { peanuts, 3/week }\end{array}$ \\
\hline 5 & 2 & Female & $\begin{array}{l}\text { At } 1 \mathrm{y} \text {, given peanut butter, } \\
\text { within } 5 \mathrm{~min} \text { developed facial } \\
\text { urticaria and angioedema only. } \\
\text { No asthma. }\end{array}$ & 3 & $\begin{array}{l}25 \\
0 \\
0\end{array}$ & $\begin{array}{l}\text { At } 1 \text { year, failed stage } 3 \text { : } \\
\text { 200mg peanut butter: } \\
\text { localized urticaria. }\end{array}$ & $\begin{array}{l}9 \text { months into home peanut OIT } \\
\text { programme. } \\
\text { No acute allergic reactions. } \\
\text { Started with } 100 \mathrm{mg} \text { peanut butter, } \\
\text { now tolerating } 2.5 \mathrm{~g} \text { peanut butter, } \\
\text { 3/week }\end{array}$ \\
\hline 6 & 13 & Male & $\begin{array}{l}\text { No history of peanut } \\
\text { consumption prior to challenge }\end{array}$ & 3 & $\begin{array}{l}100 \\
0 \\
0\end{array}$ & $\begin{array}{l}\text { At } 11 \text { years failed stage } 3 \text { : } \\
\text { 200mg of peanut: } \\
\text { abdominal pain, vomiting, } \\
\text { anxiety, itch, conjunctivitis }\end{array}$ & $\begin{array}{l}14 \text { months into home peanut OIT. } \\
\text { No acute allergic reactions. } \\
\text { Describes stinging in his mouth } \\
\text { when taking peanut after missed } \\
\text { doses. Started with } 1 / 2 \text {, now } \\
\text { tolerating one peanut } 4-7 \text { times a } \\
\text { week. }\end{array}$ \\
\hline
\end{tabular}




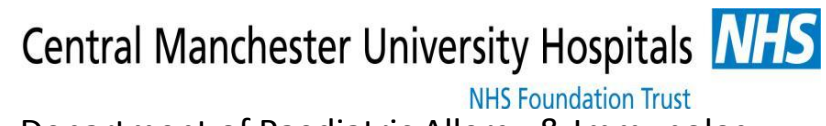

Department of Paediatric Allergy \& Immunology

Royal Manchester Children's Hospital

Oxford Rd., Manchester, M13 9WL, UK

Tel 01617015422

\section{Why have I been given this information sheet?}

A hospital oral challenge has confirmed that your child has a peanut allergy. Although your child reacted to the food, small amounts of peanut in the early stages of the challenge were tolerated without any allergy symptoms. By giving your child these small amounts of peanut at least 3 times a week and then slowly increasing the amount in your child's diet, we aim is to make your child more tolerant to peanut and less likely to have an allergic reaction if they accidently come across peanuts.

\section{What's the evidence that desensitisation works?}

Clinical trials in the UK and the USA have shown that in children with proven peanut allergy, slowly increasing the amount of peanut protein in their diet improves their tolerance to the food. ${ }^{1-3}$ Quality of life for both the child and the family also improves. ${ }^{4}$ Although peanut desensitisation is currently largely performed in research and private allergy practice settings, for cow's milk, egg and wheat this is now routine practice in our clinic, other clinics in the UK and other parts of the world. 5,6

\section{What's involved for your child?}

- Inclusion/Exclusion criteria Your child was selected for this program as they did not suffer from any breathing problems during their oral peanut challenge and their asthma is under control.

- Starting dose Based on the result of your child's peanut food challenge, we know the amount of peanut-containing food that triggered an allergic reaction. Your child will start eating one quarter of the amount of peanut-containing food that caused the reaction at least 3 times a week. For instance, if you child reacted to a teaspoon of peanut-butter he/she will start with a $1 / 4$ of a teaspoon.

- Dose escalation Every 3 weeks the amount of peanut-containing food your child eats will be doubled until they reach the equivalent of 6 - 8 peanuts 3 times a week. For example, if your child started on $1 / 4$ of a teaspoon of peanut butter 3 times a week, after 3 weeks of eating the peanutcontaining food regularly, the amount should be doubled to $1 / 2$ teaspoon, after 6 weeks to 1 teaspoon (5g) and finally after 9 weeks 2 teaspoons.

- Dose maintenance Once your child reaches the equivalent of 15 peanuts (one tablespoon), he/she needs to continue eating this amount of peanut at least 3 times a week. Stopping the peanut diet for more than 4 weeks may lead to your child losing their tolerance and becoming allergic to peanut again.

- Follow-up Your child will be followed up by your specialist every 2 - 3 months or more frequently if required. If your child does not attend his appointments, then they will be withdrawn from the programme.

\section{What are the potential benefits?}

The aim is to allow your child to be more tolerant to peanuts so that he/she can eat peanutcontaining foods and will not react to the food after accidental exposure. It should also help to lift restrictions in diet and life-style such as eating out and going on group activities. ${ }^{7}$

References 1. Varshney $\mathrm{P}$, et al. A randomized controlled study of peanut oral immunotherapy: clinical desensitization and modulation of the allergic response. J Allergy Clin Immunol. 2011. 2. Anagnostou K, et al. Efficacy and safety of high-dose peanut oral immunotherapy with factors predicting outcome. Clin Exp Allergy. 2011. 3. Anagnostou K, et al. Assessing the efficacy of oral immunotherapy for the desensitisation of peanut allergy in children (STOP II): a phase 2 randomised controlled trial. Lancet. 2014. 4. Nurmatov U et al, Allergen immunotherapy for IgE-mediated food allergy: a systematic review and meta-analysis. Allergy. 2017. 5. Burks AW et al. Oral immunotherapy for treatment of egg allergy in children. New Engl J Med. 2012. 6. Pajno GB et al. Safety profile of oral immunotherapy with cow's milk and hen egg: A 10-year experience in controlled trials. Allergy Asthma Proc. 2016. 7. Vickery BP et al. Early oral immunotherapy in peanut-allergic preschool children is safe and highly effective. J Allergy Clin Immunol, 2017. 
What are the potential risks?

- Potential risks of the peanut desensitisation program need to be weighed up with the benefits.

- It is likely that your child will experience some allergic symptoms during the program. These symptoms are likely to be minor e.g. hives, lip swelling, vomiting, particularly in preschool children. ${ }^{6}$ More severe reactions (anaphylaxis) including wheeze and difficulty breathing may occur are uncommon. An allergy management plan will be provided so you know what to do if your child suffers an allergic reaction. ${ }^{4}$

- If your child is unwell with colds, coughs or vomiting bugs, he/she may be more prone to allergic symptoms. Your child should continue with the amount, but if $s /$ he does get symptoms then the dose should be reduced by half for one week before going back up again.

- We do not know how long children remain tolerant to peanuts if they stop eating the food. We presently assume that children need to continue to eat peanut-containing food indefinitely/ without stopping at least 3 times a week to maintain their tolerance.

- If you child does not eat the peanut-containing food for more than 4 weeks, or suffers from an asthma attack requiring oral steroids (prednisolone), then you should contact your specialist before restarting the peanut diet.

What support can I expect for my child during the program?

You and your child with be counselled throughout the program and will be seen at regular intervals in a consultant-led clinic. If you have queries about your child's peanut allergy between their appointments, you can leave a message on 01617015422 during working. Your doctor will return your call. If your child has a severe allergic reaction you should follow your allergy management plan and come to the ED, just as you would do if your child was not on the programme

If you have any concerns about giving your child peanut-containing foods, you can withdraw from the program at any time and we will revert to standard follow-up for children with peanut allergy.

\section{Program discussed and agreed:}

\begin{tabular}{|l|l|l|}
\hline Patient & & \\
\hline Name & Signature & Date \\
\hline Parent & & \\
\hline Name & Signature & Date \\
\hline & & \\
\hline Specialist & & \\
\hline Name & Signature & Date \\
\hline & & \\
\hline
\end{tabular}

References 1. Varshney $\mathrm{P}$, et al. A randomized controlled study of peanut oral immunotherapy: clinical desensitization and modulation of the allergic response. J Allergy Clin Immunol. 2011. 2. Anagnostou K, et al. Efficacy and safety of high-dose peanut oral immunotherapy with factors predicting outcome. Clin Exp Allergy. 2011. 3. Anagnostou K, et al. Assessing the efficacy of oral immunotherapy for the desensitisation of peanut allergy in children (STOP II): a phase 2 randomised controlled trial. Lancet. 2014. 4. Nurmatov U et al, Allergen immunotherapy for IgE-mediated food allergy: a systematic review and meta-analysis. Allergy. 2017. 5. Burks AW et al. Oral immunotherapy for treatment of egg allergy in children. New Engl J Med. 2012. 6. Pajno GB et al. Safety profile of oral immunotherapy with cow's milk and hen egg: A 10-year experience in controlled trials. Allergy Asthma Proc. 2016. 7. Vickery BP et al. Early oral immunotherapy in peanut-allergic preschool children is safe and highly effective. J Allergy Clin Immunol, 2017. 


\section{YOUR CHILD'S PERSONALIZED PEANUT DESENSITISATION PROGRAM}

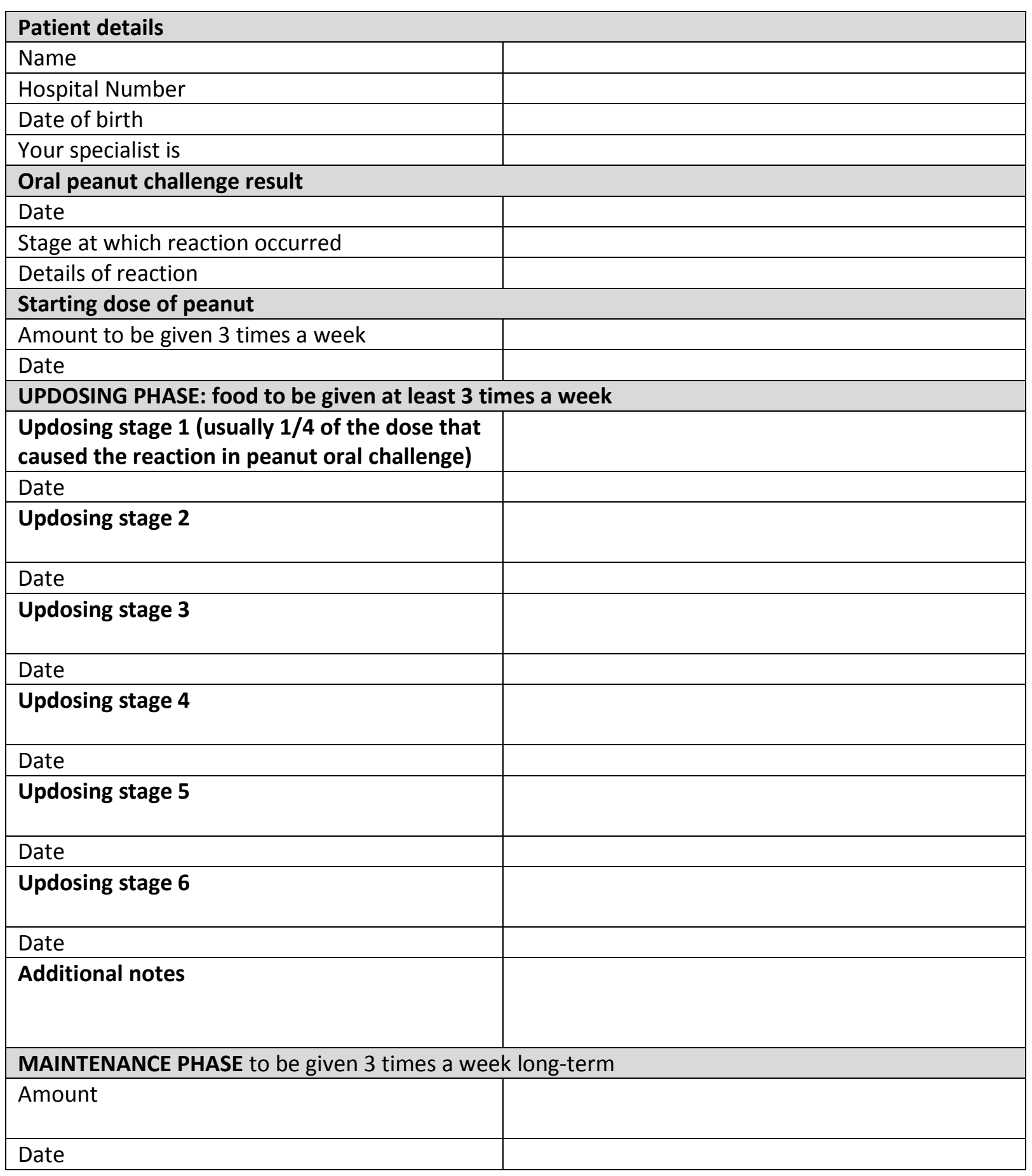

References 1. Varshney $\mathrm{P}$, et al. A randomized controlled study of peanut oral immunotherapy: clinical desensitization and modulation of the allergic response. J Allergy Clin Immunol. 2011. 2. Anagnostou K, et al. Efficacy and safety of high-dose peanut oral immunotherapy with factors predicting outcome. Clin Exp Allergy. 2011. 3. Anagnostou K, et al. Assessing the efficacy of oral immunotherapy for the desensitisation of peanut allergy in children (STOP II): a phase 2 randomised controlled trial. Lancet. 2014. 4. Nurmatov U et al, Allergen immunotherapy for IgE-mediated food allergy: a systematic review and meta-analysis. Allergy. 2017. 5. Burks AW et al. Oral immunotherapy for treatment of egg allergy in children. New Engl J Med. 2012. 6. Pajno GB et al. Safety profile of oral immunotherapy with cow's milk and hen egg: A 10-year experience in controlled trials. Allergy Asthma Proc. 2016. 7. Vickery BP et al. Early oral immunotherapy in peanut-allergic preschool children is safe and highly effective. J Allergy Clin Immunol, 2017. 